Jurnal Keuangan dan Perbankan, Vol.20, No.1 Januari 2016, hlm. 42-49

Terakreditasi SK. No. 040/P/2014

http://jurkubank.wordpress.com

\title{
APAKAH KUALITAS LABA BERBASIS AKUNTANSI BERKONTRIBUSI TERHADAP MARKET OUTCOMES?
}

\author{
Muhammad Khafid, Hasan Mukhibad \\ Jurusan Akuntansi, Fakultas Ekonomi Universitas Negeri Semarang,
}

\begin{abstract}
The purpose of this study was to analyze the effect of quality accrual, earnings persistence, and earnings predictability to market outcomes. The population in this study areall companies listed on thel ndonesian Stock Exchange (BEI), 430 companies. The samples were 233 companies which were determined by purposive sampling technique. $D$ ata collection method used is the documentation. $D$ ata analysis techniqueused is multiple regression analysis. Thestudy al so tested the classical assumption consisting of: multicollinearity, linearity, heteroscedasticity and residual normality. Thestudy states that earnings predictability variables (sig. 0,000 ) and earnings persistence (sig. 0.004) significantly affect market outcomes, whiletheaccrual of variable quality not significantly affect market outcomes at thelevel of á 0.05 . Theresearch model successfully explains thevariation of the dependent variableto $14.2 \%$ (adjusted R2 value). R esearch in the futurenecessary to find an al ternative measurement of the accrual quality and enhancethe research model can improvetheability to explain the dependent variable.
\end{abstract}

Key w ords: accruals quality, earnings persistence, earnings predictability, market outcomes.

Pernyataan Standar A kuntansi Keuangan (PSAK) Nomor 1 menyatakan bahwa informasi laba diperlukan untuk menilai perubahan potensi sumberdaya ekonomis yang dapat dikendalikan di masa depan, menghasilkan arus kas dari sumber daya yang ada, dan untuk perumusan pertimbangan tentang efektivitas perusahaan dalam memanfaatkan tambahan sumber daya (Ikatan A kuntan Indonesia, 2011). Para pemegang saham berpandangan bahwa laba merupakan peningkatan nilai ekonomis yang akan diterima melalui pembagian dividen. Laba juga digunakan sebagai salah satu indikator untuk memperkirakan prospek perusahaan di masa yang akan datang. Mengingat sedemikian strategisnya peran dari informasi laba ini, makakualitas laba menjadi hal yang amatpenting bagi para pengambil keputusan ekonomik.

Schipper dan Vincent (2003) menyatakan bahwa kualitas laba menunjukkan tingkat kedekatan laba yang dilaporkan dengan Hicksianincome, yang merupakan laba ekonomik yaitu jumlah yang dapat dikonsumsi dalam satu periodedengan menjagakemampuan perusahaan pada awal dan akhir periode tetap sama. Sesuai dengan Schipper dan Vincent,

Korespondensi dengan Penulis:

Muhammad Khafid: Telp. -

Email: - 


\section{Apakah Kualitas Laba Berbasis Akuntansi Berkontribusi terhadap Market Outcomes?}

Muhammad Khafid, Hasan Mukhibad

Suwardjono (2005) menyatakan bahwa kualitas laba akuntansi ditunjukkan oleh kedekatan atau korelasi antara laba akuntansi dan laba ekonomik.

Namun demikian, laba belum tentu dapat dipercaya untuk menjadi salah satu pertimbangan dalam pengambilan keputusan ekonomik. Pernyataan ini ditandai dengan adanya berbagai kasus penyajian laporan keuangan yang tidak semestinya. Fakta empiris tentang skandal akuntansi terjadi pada perusahaan Toshiba di Jepang yang menyebutkan nilai skandal akuntansi mencapai US\$1,2 miliar (http:/ / finansial .bisnis. com/ read/ 20150721, diunduh tanggal 21 Juli 2015).

Kajian mengenai kualitas pelaporan keuangan, tidak akan bisa lepas dari dampak yang ditimbulkan dari kualitas pelaporan keuangan tersebut. Pengertian kual itas pelaporan keuangan dapat dipandang dalam dua sudut pandang. Pandangan pertama menyatakan bahwa kualitas pelaporan keuangan berhubungan dengan kinerjakeseIuruhan perusahaan yang tergambarkan dalam laba perusahaan. Informasi pelaporan keuangan dikatakan tinggi (berkualitas) jikalaba tahun berjalan dapat menjadi indikator yang baik untuk laba perusahaan di masa yang akan datang (Fanani, 2008) atau berasosiasi secara kuat dengan arus kas operasi di masa yang akan datang (Dechow,dkk 2010). Pandangan kedua menyatakan bahwa kualitas pelaporan keuangan berkaitan dengan kinerja saham perusahaan di pasar modal. Hubungan yang semakin kuat antara laba dengan return pasar menunjukkan informasi pelaporan keuangan tersebut semakin tinggi.

Penelitian kual itas pelaporan keuangan dapat dilakukan dengan dua pendekatan (Pagalung, 2006). Pendekatan pertama adalah penelitian yang berkaitan dengan mengkaji faktor-faktor apa yang menyebabkan pelaporan keuangan yang dihasilkan berkualitas, dan pendekatan kedua sejauhmana kualitas pelaporan keuangan direspon oleh para pemakai laporan keuangan, utamanya para investor maupun investor potensial. Pendekatan kedua ini merupakan market outcomes dari kualitas pelaporan keuangan. Pendekatan kedua berkaitan dengan faktor eksternal yang merupakan respons pemakai informasi pelaporan keuangan, yaitu sejauhmana informasi pelaporan keuangan direspon oleh para pemakai laporan keuangan. Informasi pelaporan keuangan yang berkualitas dapat meningkatkan kepercayaan investor (Fanani, 2008).

Beberapa peneliti menyebut market outcomes dengan istilah kualitas laba berbasis pasar ( $\mathrm{Niu,}$ 2006; Petra, 2007). Petra (2007) menyatakan bahwa kandungan informasi dari laba bersih yang dilaporkan dapat diukur dari besarnya perubahan harga saham atau melalui besarnya return pasar abnormal di sekitar waktu pasar merespon laba bersih. Ini berarti bahwa investor yang menemukan laba yang informatif, kemungkinan merevisi kepercayaannya mengenai return di masa yang akan datang. Revisi kepercayaan ini akan mencerminkan keputusan investor dalam hal membeli/ menjual yang akan menghasilkan perubahan harga saham.

Beberapa hasil penelitian empiris secara umum mendukung pernyataan bahwa kualitas laba berpengaruh terhadap market outcomes dalam bentuk earnings response coefficient, expected return maupun abnormal return. Boediono (2005) juga memperoleh hasil yang senada. Keterkaitan antara variabel kualitas laba dengan market outcomes dan antara variabel corporate governance dengan market outcomes dapat dijelaskan dengan signaling theory (Connelly, dkk., 2011). Zhao dkk. (2004) menyatakan bahwa teorisinyal mengkaji tentangteknikpelaporan,dimana perusahaan-perusahaan yang baik mencoba untuk membedakan diri dari perusahaan berkualitas buruk dengan menggunakan tehnik pelaporan yangberbeda. Dengan demikian, kualitas laba yang ditampilkan oleh perusahaan, merupakan sinyal yang akan direspon oleh pasar. Respon pasar terhadap pelaporan keuangan perusahaan termasuk di dalamnya pelaporan laba dapat diidentifikasi melalui market outcomes (Dimitropoulos, dkk., 2009). 


\section{Jurnal Keuangan dan Perbankan | KEUANGAN}

Vol. 20, N o.1, Januari 2016: 42-49

Penelitian ini akan menguji kualitas laba dengan tiga pendekatan yakni kualitas akrual, persistensi laba dan prediktabilitas laba.Penelitian ini bertujuan untuk menguji dan menganalisis: pengaruh kualitas akrual laba, persistensi laba, dan prediktabilitas labaterhadap market outcomes.

\section{Metode}

Desain penelitian ini merupakan penelitian hypothesis testing study (Sekaran, 2000). Dilihat dari sifat eksplanasi ilmu, penelitian ini termasuk ke dalam penelitian kausalitas (Ferdinand, 2011). Penelitian ini menggunakan data sekunder, karena data dikumpulkan dari sumber-sumber data yang telah ada (Sekaran, 2000). Data yang digunakan dalam penelitian ini bersumber dari laporan keuangan perusahaan yang terdaftar di Bursa Efek Indonesia (BEI) selama periode tahun 2008 sampai tahun 2013. Data tersebut bisa diperoleh dari Indonesian Capital M arket Directory (ICMD), dan annual report.

Populasi penelitian ini adalah seluruh perusahaan yang terdaftar di Bursa Efek Indonesia (BEI). Jumlah perusahaan yang terdaftar di Bursa Efek Indonesia (BEI) berdasarkan data per 1 Januari 2014 adalah sebanyak 430 perusahaan (www.idx.co.id). Sampel penelitian berjumlah 233 perusahaan yang dipilih berdasarkan kriteria tertentu (purposive sampling).

Ringkasan mengenai definisi operasional dan cara pengukuran variabel disajikan dalam Tabel 1 berikut ini:

M etode pengumpulan data yang digunakan dalam penelitian ini adalah dokumentasi. Metode anal isis data yang digunakan dalam penelitian ini adalah analisis statistik deskriptif dan analisis

Tabel 1. Ringkasan Variabel Penelitian

\begin{tabular}{|c|c|c|c|}
\hline No. & $\begin{array}{l}\text { Variabel } \\
\text { Penelitian }\end{array}$ & Definisi Operasional & Cara Pengukuran \\
\hline 1. & $\begin{array}{l}\text { Kualitas laba } \\
\text { dengan } \\
\text { indikator } \\
\text { Kualitas A krual }\end{array}$ & $\begin{array}{l}\text { A ccruals quality (kualitas akrual) } \\
\text { merupakan ukuran kualitas laba } \\
\text { yang didasarkan pada pandangan } \\
\text { bahwa laba yang mendekati aliran } \\
\text { kas adalah laba yang memiliki } \\
\text { kualitas yang lebih baik. }\end{array}$ & $\begin{array}{l}\text { total accruals as the difference between net } \\
\text { income and operating cash flows, scaled by } \\
\text { lagged total assets. (H uang dkk, 2007). }\end{array}$ \\
\hline 2. & $\begin{array}{l}\text { Kualitas Laba } \\
\text { dengan } \\
\text { indikator } \\
\text { Persistensi laba }\end{array}$ & $\begin{array}{l}\text { Persistensi laba merupakan ukuran } \\
\text { kualitas laba yang didasarkan pada } \\
\text { pandangan bahwa laba yang lebih } \\
\text { sustainable adalah laba yang } \\
\text { memiliki kualitas yang lebih baik. }\end{array}$ & $\begin{array}{l}\text { Koefisien regresi dari earnings per share } \\
\text { periode yang lalu terhadap earning per } \\
\text { share periode sekarang. }\end{array}$ \\
\hline 3. & $\begin{array}{l}\text { Kualitas Laba } \\
\text { dengan } \\
\text { indikator } \\
\text { Prediktabilitas } \\
\text { laba }\end{array}$ & $\begin{array}{l}\text { Prediktabilitas laba didefinisikan } \\
\text { sebagai ukuran kualitas laba yang } \\
\text { didasarkan atas kemampuan laba } \\
\text { untuk memprediksi laba itu sendiri. }\end{array}$ & $\begin{array}{l}\text { Deviasi standar dari laba bersih. Nilai } \\
\text { deviasi standar yang besar menunjukkan } \\
\text { kualitas laba yang rendah. }\end{array}$ \\
\hline 4. & $\begin{array}{l}\text { M arket } \\
\text { outcomes }\end{array}$ & $\begin{array}{l}\text { M arket outcomes adalah cost of capital } \\
\text { yang merupakan return yang } \\
\text { diminta oleh para pemilik modal. }\end{array}$ & $\begin{array}{l}\text { Cummulative abnormal return selama } 11 \\
\text { hari, yaitu } 5 \text { hari sebelum publikasi, } 1 \text { hari } \\
\text { pada saat publikasi, dan } 5 \text { hari sesudah } \\
\text { publikasi laporan keuangan }\end{array}$ \\
\hline
\end{tabular}

Sumber: dikembangkan untuk penelitian ini. 


\section{Apakah Kualitas Laba Berbasis Akuntansi Berkontribusi terhadap Market Outcomes?}

Muhammad Khafid, Hasan Mukhibad

statistik inferensial. A nalisis statistik deskriptif digunakan untuk menggambarkan profil variabel penelitian yang terdiri atas: kualitas akrual laba, persistensi laba, prediktabilitas laba, dan market outcomes.A nalisis statistik inferensial digunakan untuk menguji hipotesis penelitian. Analisis statistik inferensial yang digunakan adalah analisis regresi berganda dengan menggunakan bantuan software SPSS release 19.0. Untuk menghasilkan model penelitian yang BLUE (Best, Linear, U nbiased Estimator) maka dilakukan uji asumsi klasik yang terdiri atas pengujian multikolinearitas, heteroskedastisitas, normalitas, dan linearitas.

\section{Hasil dan Pembahasan}

Sampel penelitian sebanyak 233 perusahan yang diperoleh dari teknik purposive sampling dengan tahapan sebagaimana disajikan padaTabel 2.

Uji normalitas residual dilakukan dengan cara melihat Normal P-P Plot of Regression Standardized Residual. Berdasarkan Normal P-P Plot of Regression Standardized Residual menunjukkan bahwa residual terdistribusi normal (Ghozali, 2011: 176). Hasil uji multikolinieritas menunjukkan bahwa N ilai VIF pada collinearity statistics tidak ada yang melebihi angka 10. Hal ini mengindikasikan tidak terdapat multikolinieritas (Ghozali, 2011: 174). Di samping itu, nilai toler ance tidak ada yang kurang dari 0,10, sehingga juga dapat disimpulkan bahwa tidak terdapat multikolinieritas di dalam model regresi yang disusun (Ghozali, 2011: 174).

Untuk menguji heteroskedasitas, digunakan Uji Glejser (Ghozali, 2011:142). Berdasarkan Uji Glejser diketahui bahwa nilai signifikansi tsebesar 0,903 (kual itas akrual), 0,523 (persistensi laba), dan 0,341 (In prediktabilitas laba). Hasil ini menunjukkan bahwa seluruh variabel independen tidak signifikan mempengaruhi variabel absolut unstandardized residual. Oleh karena itu dapat disimpulkan bahwa model regresi tidak mengandung adanya heteroskedastisitas.

$\mathrm{H}$ asil pengujian linearitas, diperoleh nilai Durbin-Watson sebesar 2,020. Nilai D-W tabel untuk $\mathrm{n}=233$ dan $\mathrm{k}=3$ adalah $\mathrm{dl}=1,686$ dan $\mathrm{du}=1,852$ (menggunakan tabel dengan $n=200$, karena angka $\mathrm{n}$ maksimal yang tersedia di tabel adalah 200). Oleh

Tabel 2. Proses Pemilihan Sampel Penelitian

\section{Kriteria Pemilihan Sampel dan Keterangan}

Populasi penelitian = jumlah seluruh perusahaan yang terdaftar di Bursa Efek Indonesia

(BEI) per 1Januari 2014 (sumber: www.idx.co.id)

Dikurangi:

Perusahaan yang terdaftar di BEI sesudah tahun 2008

Dikurangi:

Perusahaan yang tidak ditemukan annual report nya untuk tahun 2008 - 2013 dalam masa

pengumpulan data (Bulan Juni 2015)

Dikurangi:

Data mengenai harga saham pada periode pengamatan tidak tersedia secara lengkap

Dikurangi:

Data outlier 


\section{Jurnal Keuangan dan Perbankan | KEUANGAN}

Vol. 20, N o.1, Januari 2016: 42-49

karena angka Durbin-Watson berada di atas nilai D-W du, maka dapat disimpulkan model tidak sal ah spesifikasi.

Hasil pengujian statistik tentang signifikansi keseluruhan variabel independen terhadap variabe dependen dapat dilihat pada Tabel 3.

Tabel 3 membuktikan bahwa secara simultan keseluruhan variabel independen secara signifikan berpengaruh terhadap market outcomesdengan signifikansi $F$ sebesar 0,000 yang berada di bawah angka 0,05 sebagai batas taraf signifikansi .Besarnya kemampuan variasi dari keseluruhan variabel independen menjelaskan variasi variabel dependen (market outcomes) sebesar 0,142, sedangkan sebanyak $85,8 \%$ variasi dari variabel dependen dijelaskan oleh variabel lain yang tidak diteliti dalam penelitian ini (Tabel 4).

H asil pengujian statistik signifikansi masingmasing variabel independen terhadap variabel dependen secara parsial dapat dilihat pada Tabel 5.

Tabel 5 menginformasikan bahwa kualitas laba akrual tidak berpengaruh secara signifikan terhadap market outcomes, dibuktikan dengan angka signifikansi t sebesar 0,063 (lebih besar dari angka alfa 0,05).Persistensi laba berpengaruh secara signifikan terhadap market outcomes, dibuktikan

Tabel 3. Hasil Uji $F$

\begin{tabular}{llccccc}
\hline M odel & & Sum of Squares & Df & M ean Square & F & Sig. \\
\hline 1 & Regression & 1,405 & 3 &, 468 & 13,748 &, $000^{\mathrm{a}}$ \\
& Residual & 7,804 & 229 &, 034 & & \\
& Total & 9,209 & 232 & & & \\
\hline
\end{tabular}

a. Predictors: (Constant), In_pred, k_akrual, persist

b. Dependent Variable: market_out

Sumber: Data penelitian diolah.

Tabel 4. M odel Summary

\begin{tabular}{cccccc}
\hline M odel & $\mathbf{R}$ & R Square & $\begin{array}{c}\text { Adjusted } \mathbf{R} \\
\text { Square }\end{array}$ & $\begin{array}{c}\text { Std. Error of the } \\
\text { Estimate }\end{array}$ & Durbin-Watson \\
\hline 1 &, $391^{\mathrm{a}}$ &, 153 &, 142 &, 18459840 & 2,210 \\
\hline
\end{tabular}

a. Predictors: (Constant), In_pred, k_akrual, persist

b. Dependent Variable: market_out

Sumber: Data penelitian diolah.

Tabel 5. Hasil Uji t

\begin{tabular}{|c|c|c|c|c|c|c|c|c|c|}
\hline \multirow{2}{*}{\multicolumn{2}{|c|}{ M odel }} & \multicolumn{2}{|c|}{$\begin{array}{l}\text { Unstandardized } \\
\text { Coefficients }\end{array}$} & \multirow{2}{*}{$\begin{array}{c}\text { Standardized } \\
\text { Coefficients } \\
\text { Beta }\end{array}$} & \multirow[b]{2}{*}{$\mathbf{t}$} & \multirow{3}{*}{$\frac{\text { Sig. }}{, 000}$} & \multicolumn{2}{|c|}{ Correlation } & \multirow[b]{2}{*}{ Part } \\
\hline & & B & Std. Error & & & & Zero-order & Partial & \\
\hline \multirow[t]{4}{*}{1} & (Constant) &,- 730 & ,160 & & $-4,568$ & & & & \\
\hline & Persist & 083 & ,029 & 179 & 2,906 & 004 & 230 & 189 & 177 \\
\hline & k_akrual & 196 & 105 & 114 & 1,867 & 063 & 134 & 122 & 114 \\
\hline & In_pred &,- 031 &, 006 &,- 296 & $-4,813$ & 000 & ,325 & ,303 & ,293 \\
\hline
\end{tabular}




\section{Apakah Kualitas Laba Berbasis Akuntansi Berkontribusi terhadap Market Outcomes?}

Muhammad Khafid, Hasan Mukhibad

dengan angka signifikansi t sebesar 0,004 (lebih kecil dari angka alfa 0,05). Prediktabilitas laba berpengaruh secara signifikan terhadap market outcomes, dibuktikan dengan angka signifikansi t se besar 0,000 (lebih kecil dari angka alfa 0,05). N ilai koefisien regresi yang bertanda negatif bermakna bahwa arah pengaruh variabel prediktabilitas laba adalah negatif.

Pengukuran variabel kualitas akrual dalam penelitian ini menggunakan pengukuran Huang dkk., (2007) yang menyatakan bahwa total accruals as the differ ence between net income and operating cash flows, scaled by lagged total assets. Menurut ukuran ini, laba yang berkual itas adalah laba yang memiliki kedekatan dengan arus kas dari aktifitas operasi.

Temuan ini tidak selaras dengan preposisi yang dibentuk dimana kualitas akrual sebagai salah satu ukuran kualitas laba diprediksi mempengaruhi market outcomes. Kualitas laba didasarkan pada hubungan laba-kas-akrual dapat diukur dengan berbagai ukuran, yaitu: rasio kas operasi dengan laba, perubahan akrual total, estimasi abnormal/discretionary accruals (akrual abnormal/ kebijakan), dan estimasi hubungan akrual-kas (Schipper dan Vincent, 2003). Dengan menggunakan ukuran rasio kas operasi dengan laba, kualitas laba ditunjukkan oleh kedekatan laba dengan aliran kas operasi. Laba yang semakin dekat dengan aliran kas operasi mengindikasikan laba yang semakin berkualitas. Dengan menggunakan ukuran perubahan akrual total, laba berkualitas adalah laba yang mempunyai perubahan akrual total kecil.

Jika ditelaah lebih lanjut, temuan penelitian ini yang menyatakan bahwa kualitas akrual tidak berpengaruh terhadap market outcomes bisa dipahami dan masuk akal, mengingat para investor dan cal on investor biasanya mel ihat laba yang baik adalah laba yang meningkat, stabil dari periode ke periode. Investor dan calon investor diduga cenderung tidak memperhatikan kedekatan laba bersih dengan arus kas dari aktifitas operasi.
Kualitas laba perusahaan yang diukur melalui persistensi laba dipercaya oleh para investor dan calon investor, sehingga pasar merespon positif atas informasi laba yang disampaikan. Perusahaan dengan laba yang lebih persisten direspon oleh pasar secara lebih positif dibandingkan dengan perusahaan yang memiliki laba yang kurang persisten (Petra, 2007; Zhao, 2007; Oei, dkk., 2008; Khafid, 2013). Temuan penelitian ini mendukung teori signal yang menyatakan bahwa sebuah perusahaan yang baik dapat membedakan dirinya dari perusahaan yang buruk dengan mengirimkan sinyal yang kredibel tentang kualitas perusahaan tersebut kepada pasar modal.

Perusahaan yang memiliki laba dengan nilai prediktabilitas yang tinggi akan direspon pasar secara positif sehingga nilai market outcomes meningkat (Cahan, dkk., 2009). Prediktabilitas laba pada penelitian ini diukur dari deviasi standar laba bersih. N ilai deviasi standar yang lebih besar menunjukkan kualitas laba yang rendah (prediktabilitas laba rendah). Hal ini berarti perusahaan dengan prediktabilitas laba yang semakin tinggi (nilai deviasi standar semakin kecil) menyebabkan market outcomes semakin meningkat. Hasil penelitian ini selaras dengan temuan Francis dkk. (2006) yang menemukan bahwa return perusahaan dipengaruhi oleh prediktabilitas laba.

\section{KESIM PULAN}

Berdasarkan hasil penelitian disimpulkan beberapa hal sebagai berikut:

1. Kualitas akrual tidak berpengaruh secara signifikan terhadap market outcomes. Hal ini berarti bahwa kualitas akrual sebagai salah satu ukuran kualitas Iaba berbasis akuntansi tidak dijadikan pertimbangan bagi para investor dan calon investor dalam pengambilan keputusan pembelian saham perusahaan.

2. Persistensi laba berpengaruh secara positif signifikan terhadap market outcomes. Hal ini 


\section{Jurnal Keuangan dan Perbankan | KEUANGAN}

Vol. 20, N o.1, Januari 2016: 42-49

berarti semakin tinggi persistensi laba perusahaan, maka semakin tinggi market outcomes.

3. Prediktablilitas laba berpengaruh secara positif signifikan terhadap market outcomes. Hal ini bermakna perusahaan yang memiliki prediktabilitas laba lebih tinggi akan direspon positif oleh pasar sehingga market outcomes meningkat.

\section{SARAN}

Berdasarkan simpulan, saran dari penelitian ini adalah:

1. penelitian ini berhasil membuktikan bahwa persistensi laba dan prediktabilitas Iaba berpengaruh terhadap market outcomes. Oleh karena itu, kepada para investor, calon investor, dan para analis pasar modal disarankan untuk mempertimbangkan persistensi laba dan prediktabilitas laba dalam pengambilan keputusan pembelian saham.

2. Pengukuran kualitas akrual dalam penelitian ini mendasarkan pada ukuran kualitas akrual Huang, dkk (2007) yang membandingkan antara laba bersih dan jumlah arus kas dari aktivitas operasi. Ukuran ini menitikberatkan pada kedekatan antara laba dan arus kas. Namun demikian ukuran ini belum mempertimbangkan nilai positif/ negatif dari perbandingan ini (laba bersih > arus kas ataukah laba bersih < arus kas). Hal ini juga yang diduga menjadi salah satu sebab ditolaknya hipotesis 1 penelitian ini. Oleh karena itu, kepada peneliti yang akan datang dapat menggunakan ukuran kualitas akrual yang lain untuk penelitian sejenis.

\section{DAFTAR PUSTAKA}

Boediono, G.S.B. 2005. Kualitas Laba: Studi Pengaruh Mekanisme Corporate Governance dan Dampak Manajemen Laba Dengan Menggunakan Analisis Jalur. Prosiding, Simposium Nasional Akuntansi VIII. Surakarta.
Cahan, S.F., Emanuel, D., and Sun, J. 2009. The Effect of Earnings Qual ity and Country level Institution on The Value Relevance of Earnings. Rev Quant Finance and A ccounting. Vol. 33. Pp. 371 - 391.

Connelly, B.L., Certo, S.T., Ireland, R.D., and Reutze, C.R. 2011. Signaling Theory: A Review and Assessment. Journal of M anagement. Vol. 37. Pp. 39 - 67.

Dechow, P.M . and I. Dichev. 2002. The Quality of Accruals and Earnings: The Role of Accrual Estimation Errors. The A ccounting R eview 77. Supplement: 3559.

Dechow, P.M., Ge, W., and Schrand, C. 2010. Understanding Earnings Quality: A Review of The Proxies, Their Determinantsand Their Consequences. Journal of A ccounting and Economics. Vol. 50. Pp. 344 401.

Dimitropoulos, P.E., and Asteriou, D. 2009. The Value Relevance of Financial Statements and Their Impact on Stock Prices: Evidence of Greece. $M$ anagerial A uditing Journal. Vol. 24. No. 3. Pp. 248 - 265.

Fanani, Z. 2008. Kualitas Pelaporan Keuangan: FaktorFaktor Penentu dan Konsekuensi ekonomiknya. The 2nd A ccounting Conference, 1st Doctoral Colloquium, and Accounting Workshop Depok. Universitas Indonesia. Jakarta.

Ferdinand, A. 2011. M etodePenelitian M anajemen, Pedoman Penelitian untuk Penulisan Skripsi, Tesis, dan D isertasi IImu M anajemen. Badan PenerbitUndip. Semarang.

Francis, J., Olsson, P., and Schipper, K.. 2006. Earnings Quality. Foundation and Trends in Accounting. Vol. 1. No. 4. Pp. 259 - 340.

Ghozali, I. 2001. A plikasi A nalisis M ultivariate dengan Program IBM SPSS 19. Badan Penerbit Universitas Dipenogoro, Semarang.

http:// finansial.bisnis.com/ read/ 20150721. "Toshiba Diguncang Skandal Akuntansi Senilai US\$1,2Miliar. Diakses Tanggal 21 Juli 2015.

Huang, P., Louwers, T.J., M offit, J.S., and Zhang, Y. 2007. "Ethical Management, CorporateGovernance, and A bnormal Accruals. Journal of Business Ethics. Vol. 83. Pp. 469 - 487.

Ikatan A kuntan Indonesia. 2011. Standar A kuntansi Keuangan. Salemba Empat. Jakarta. 


\section{Apakah Kualitas Laba Berbasis Akuntansi Berkontribusi terhadap Market Outcomes?}

Muhammad Khafid, Hasan Mukhibad

Khafid, M. 2013. Pengaruh Tata Kel ola Perusahaan (Corporate Governance) dan Struktur Kepemilikan terhadap Persistensi Laba. Jurnal Dinamika A kuntansi. Vol. 4. No. 2.

Niu, F.F. 2006. CorporateGovernanceand The Quality of Accounting Earnings: a Canadian Perpective. International Journal of $\mathrm{M}$ anagerial Finance. Vol. 2. No. 4. Pp. 302 - 327.

Oei, R., Ramsay, A., and Mather, P. 2008. Earnings Persistence, Accruals and Managerial Sahre Ownership. A ccounting and Finance. Vol. 48. Pp. 475- 502.

Pagalung, G. 2006. Kualitas Informasi Laba: FaktorFaktor Penentu Dan EconomicConsequencesnya. Disertasi (Tidak Dipublikasikan). Program Pascasarjana Universitas Gajah Mada. Yogyakarta.

Petra, S.T. 2007. The Effects of Corporate Governance on The Informativeness of Earnings. Economics of G overnance. Vol. 8. Pp. 129- 152.
Schipper, K., and Vincent, L. 2003. Earnings Quality. A ccounting Horizon. Vol. 17. Pp. 97 - 110.

Sekaran, U. 2000. Research M ethods for Business. John Wiley $\&$ Son. New York.

Suwardjono. 2005. Teori A kuntansi: Perekayasaan Pelaporan Keuangan. Jogjakarta: BPFE.

Zhao, J., Katchova, A.L., Barry, P.J. 2004. Testing the Pecking Theory and the Signaling Theory for Farm Businesses. Prosiding,Pertemuan Tahunan American Agricultural Economics Association, 1 - 4Juli 2004.

Zhao, R., Millet-Reyes, B., 2007. Ownership Structureand Accounting Information Content: Evidence from France. Journal of International Financial $\mathrm{M}$ anagement and Accounting. Vol. 18. No. 3. Pp. 223- 247. 